\title{
PECULIARITIES OF FINANCIAL AND LEGAL REGULATION IN THE FIELD OF TRANSPLANTATION: CURRENT STATE AND DEVELOPMENT PROSPECTS
}

\begin{abstract}
Authors in the article analysed the current state and development prospects of financial and legal regulation in the field of transplantation. In the context of reforming the entire system of domestic health care, the problem of financial and legal regulation in the field of transplantation becomes relevant. The purpose of the article is to study the financial and legal regulation in the field of transplantation, highlight its problems and form the prospects for improvement. After a throughout analysis of all peculiarities of the transplantation in the light of law and medicine issues authors stated the barriers which should be lifted in order to open the production capacities of medical institutions in this area, which are now used by $15-25 \%$, or not used at all. This, at present, is insufficient: with a huge demand for such operations, very few of them are carried out, and public funds are spent on the treatment of citizens abroad, although in Ukraine it would be many times cheaper.
\end{abstract}

Keywords: financial and legal regulation, regulatory and legal support, transplantation

\section{INTRODUCTION}

The development of the field of transplantation calls society into a so-called duel between transplantologists, the population and the state, since a significant number of questions and problems arise in various areas of this activity. Since, firstly, a significant number of patients are in great need of organ transplantation, which are extremely necessary for their life, without which, unfortunately, death will occur; secondly, society today cannot fully implement this activity due to imperfect regulatory and legal support and due to insufficient funding, which is not provided either by the state budget, or in the Government Program "Affordable Medicines", or financing it locally by individual territorial communities and the like; thirdly, medical professionals who start working in the field of transplantation, work without regulatory support, and thus expose themselves to relevant risks from a legal point of view.

\footnotetext{
${ }^{1}$ Oksana Kuzmenko, Doctor in law, associate professor, Deputy Director of Law Institute of Kyiv National Economic University named after Vadym Hetman, Kyiv, Ukraine; e-mail: cimba.71@mail.ru. ORCID: 0000-0002-0830-766X.

2 Oksana Strelchenko, Doctor in law, associate professor, Professor of the Department of Public and Administrative Management, National Academy of Internal Affairs, Kyiv, Ukraine (corresponding author); e-mail: strel1977@ukr.net. ORCID: 0000-0001-5965-9764.
} 
Accordingly, certain significant problems arise in the field of transplantation, without which it will be impossible to bring the area under study to the appropriate level of implementation, namely: 1) introduction and implementation of the principle of "presumption of consent" into the current legislation; 2) introduction of such instruments as transplantation "organ waiting lists"; 3 ) introduction of effective digitalization in the field of transplantation; 4) active grass-roots outreach; 5) introduction of the Unified database for registration of recipients and donors (i.e., those who have expressed a desire and have given their consent on their own or have the consent of relatives or persons replacing them for donation), as well as the Register of matching donor organs; 6) providing funding for the field of transplantation at all stages of its public administration (at the state and local levels), etc.

\section{LITERATURE OVERVIEW}

The problems of financial and legal regulation in the field of transplantation have been studied for many years from different points of view. So, S. Grinchak, considered these issues from the point of view of criminal law (Grynchak, 2017). Many scientists are in favour of the use of the "presumption of consent", since it will save many lives without requiring additional funding from the state budget, and it is also the most effective step to prevent illegal organ transplantation (Kraynik, 2017). The same topic was touched upon by (Mykhaylenko, Solovey, 2006; Musiyenko, 2004) and other researchers. Ya.A. Trinyova in her work pointed out that changes in legislation are important, while, first of all, she saw the need to deploy broad ideological work with the population (Trinyova, 2015). Today, both in the conditions of active reforming of the healthcare sector and with such a complex sanitary and epidemiological situation in the world, this problem is gaining significant relevance and scientific researches are being conducted to solve it.

\section{RESEARCH AND DISCUSSION}

In the past few years, the problem of transplantation of organs and anatomical materials to humans has received a new round of popularity both among scientists and among medical workers and the population.

This problem of transplantation is quite actively broadcast on television, on the Internet, on the pages of the print media, both in the form of stories about recipients awaiting transplantation of vital organs abroad, and on the part of public and charitable organizations that help carry out organ and other human anatomical materials transplantation.

We consider it expedient to look into the historical past of the formation and development of transplantation. The first mention of a successful transplant dates back to the 13th century. It is presented in the form of a legend about the life of the holy martyrs, doctors Cosmas and Domian, who were supposed to miraculously replace a sick leg with a healthy one taken from a dead person. This successful procedure is immortalized in paintings that are found in many countries. In subsequent centuries, similar information about transplantation is also found, although they have no historical confirmation. For the first time organ transplantation from a deceased person to a living one was performed in 1931 by V.P. Filatov at the Odessa Medical Institute. The doctor performed a corneal transplant from a deceased donor (Bryukhovetska, 2017). The origins of Russian transplantology are associated with the name of the outstanding surgeon N.I. Pirogov, who back in 1835 gave a lecture "About plastic surgery in general and especially about plastic 
surgery of the nose" and analysed in detail the problem of organ and tissue transplantation. The era of transplantation began in 1902 in Vienna with an attempt at a canine kidney transplant by E. Ullmann. The very first attempt to transplant a kidney to a person (a monkey was a donor) was carried out in 1936 in Berlin. The operation was unsuccessful. The attempt of the Ukrainian scientist $\mathrm{Yu}$.Yu. Voronin to transplant a kidney from a healthy person to a patient in the same year 1936 was also unsuccessful. Only two decades later (in 1954, Boston, USA) the first successful kidney transplant operation was performed, in which the recipient and donor were identical twins. As a result of this operation, which was performed by J. Murray and J. Merrill, the operated patient lived for more than 20 years (https://www.ifnmu.edu.ua/images/biblioteka/nashi_resursi/medichni_vistavki/2018/Peres adka_organiv.pdf).

It is necessary to pay attention to the fact that even despite all the regulatory, financial and legal obstacles in the field of transplantation, Ukraine was among the first to carry out it. So, back in 1933 in our country, surgeon Yuriy Voronin made an attempt to transplant a kidney from a healthy person. This operation was the first transplant of its kind. However, today, in Ukraine, more than 8000 people are on haemodialysis (treatment of acute and chronic renal failure using the "artificial kidney" apparatus), and some of them are awaiting kidney transplantation (Transplantology in Ukraine; Strelchenko, Lychenko, Shevchenko, 2018). This confirms that the development of transplantation requires the fastest development in order to preserve the health and life of people.

Today in Ukraine there are quite a few centres, hospitals and other medical institutions that are capable of transplanting organs and other human anatomical materials. So, as of May 1, 2021, there are only six transplant centers in Ukraine, which are licensed to carry out transplantations (National Institute of Surgery and Transplantology named after A.A. Shalimov; Lviv Regional Clinical Hospital; Odesa Regional Clinical Hospital; Regional Clinical Centre of Urology and Nephrology named after Shapoval (Kharkiv); Zaporizhya Regional Clinical Hospital; Dnipropetrovsk Regional Clinical Hospital named after I.I. Mechnikov etc.), where heart, liver and kidneys are already being transplanted, and the like.

For comparison, it should be noted that, for example, in Spain there are more than 40 centres for transplantation of organs and other human anatomical materials per 47 million of the population, where the number of transplants ranges from 99-120 transplants per year.

In general, in developed countries, organ transplantation is the standard treatment for many diseases of the kidneys, heart, liver, lungs, intestines, etc. One-year and five-year survival rates for organ transplants from cadaverous donors in the United States are: kidneys - 94.2 and $80.7 \%$, liver -86.3 and $72.1 \%$, heart -85.6 and $72.0 \%$, respectively (Gorodetska, 2012).

To date, for more than 35 years of clinical transplantation, approximately 2500 kidney transplants, 20 liver transplants, 10 heart transplants, 5 pancreas transplants have been performed in Ukraine. It is necessary to focus on the fact that small intestine transplants have not been carried out in Ukraine at all, only the large intestine has been partially implanted.

It is advisable to note quite significant achievements in the global transplantology, the transplants are carried out much more actively abroad than in Ukraine. Thus, kidney transplants are actively carried out, which averages more than 150 transplants per year. For example, in 2020, 55611 organ transplants were performed in the United States, while only 226 were performed in Ukraine last year, of which 215 were kidney transplants, 6 liver transplants, 4 heart transplants and 1 lungs (Strelchenko, Okhrimenko, Pavlov, 2020). At 
the same time, it should be noted that a greater number of transplants were performed from a living donor, and only three transplants were made from a dead donor in the cities of Zaporizhya, Donetsk and Dnipropetrovsk.

Today, 1,894 people with transplanted organs live on the territory of Ukraine. The number of organ transplants in Ukraine does not exceed 100-120 per year. Basically, kidney transplantation is performed from a living related donor $(90 \%)$, which is 1.6 per 1 million of the population, while in Austria this figure is 81.5, in Spain - 85.6, in the USA - 76 . 7 per million of population (Gorodetska, 2012).

Liver transplantation is mainly performed from a living donor, liver and heart transplants from a corpse donor are rare. During 2020, 47 cadaveric seizures were carried out, which amounted to 0.3 donors per 1 million of population. At the same time, according to preliminary estimates, 40-60 potential donors per 1 million of the population die in Ukraine every year, which is about 3000 potential donors who could save the lives of 10 thousand patients (Gorodetska, 2012).

It should be noted that the annual need for organ transplants in Ukraine is as follows: 3653 operations, of which kidney transplants -2115 , liver -830 , pancreas - 30, pancreas plus kidney complexes -89 , hearts -328 , lungs -240 , complex "heart - lungs" -3 , intestines -42 . However, the share of organ transplant operations is only $0.8 \%$ of all operations. The statistics are terrifying, because according to the Ministry of Healthcare of Ukraine in 2016 only 5 liver transplants were performed in Ukraine, 2 cadaveric kidney transplants and 93 family ones (Moroz, 2017), in 2017, a total of 118 operations were performed, in 2018 - 96 ones (Goncharenko, 2018) (before the coming into force of the current Law of Ukraine "On use of transplantation of anatomical materials by humans"), and in 2019 and the beginning of 2020 only 9 organ transplant operations were performed (2 - heart transplant, 7 - kidney transplant), 3 of which were from deceased donors (Official site of the Ministry of Health).

That is why an urgent study of topical problems in the development of transplantation at the scientific, national and international levels is so important.

It should be noted that the field of transplantation requires careful research, study, analysis and improvement by means of effective ways of its active implementation into the current domestic legislation, without violating the rights of donors, recipients and medical transplant specialists.

Thus, the outstanding problems in the field of transplantation that need to be solved and without which it will be impossible for the studied area to reach the appropriate level of implementation are the following: 1) lack of clear vertical subordination of public administration subjects in the field of transplantation during the recovery of donor organs; 2) the lack of the "presumption of consent" principle in the activity of transplantation and its absence at the legislative level; 3) low level of popularization of organ transplantation and other human anatomical materials; 4) insufficient procedures for diagnosing brain death as a mandatory medical procedure that must precede the recovery of a donor organ for the purpose of transplantation to its recipient; 5) insufficient funding and material and technical support to conduct a study on the compliance of a donor organ with a recipient and the absence of a single register of donors, whose organs can best suit a particular recipient; 6) lack of a unified database for registration of recipients and donors; 7) the absence of a single controlling body of public administration in the field of transplantation; 8) lack of funding for the field of transplantation at all stages of its implementation; 9) the absence of an ombudsman in the field of health care, whose powers should include protection the rights 
of donors, recipients and medical transplant specialists; 10) imperfection of legal liability for violation of the mechanism of organs and other human anatomical materials transplantation; 11) the lack of a course of transplantation in medical institutions, resulting in medical workers ignorance in the field of transplantation.

We consider it expedient to investigate the indicated problems of the development of the sphere of organ and other human anatomical materials transplantation.

When carrying out transplantation, a mandatory permit for transplantation of organs or other human anatomical materials is required - that is, the principle of "presumption of consent" or "presumption of refusal" must be applied. In various foreign countries, it is interpreted in different ways.

The main problem in organ transplantation is the lack of organs and potential donors willing to donate their organs. At the heart of this problem of obtaining an organ for a recipient is the patients' consent to the recovery of their organs after their biological death, which is the basis of the principle of "presumption of consent" in the field of transplantation. In every country of the world, this problem is solved using the principle of "presumption of refusal" ("opting in") or "presumption of consent" ("opting [or contracting] out").

It is necessary to pay attention to the fact that one of the most problematic issues is the moral and ethical aspects of transplantation from the deceased. So, each person during his lifetime can give or not give consent to donation. But in the case when this issue has not been unambiguously resolved, it is argued that it is necessary to obtain consent for the organ harvesting from the husband / wife or close relatives, which personify the presence of hereditary rights of the latter to the organs of a potential donor. This aspect is governed by Art. 16. The Law of Ukraine "On transplantation of organs and other human anatomical materials", which provides for the possibility of organs and other anatomical materials recovery from a corpse donor, provided that a capable and adult person during his lifetime declared his consent or disagreement with the posthumous organs recovery. If there is no such statement, then this consent can be obtained from close relatives. That is, in fact, there is a presumption of refusal, which is the cause of disputes around this law (Gorodetska, 2012).

Now the presumption of refusal is valid in $64 \%$ of countries where transplant procedures are performed, namely the USA, Germany, France, Canada. Accordingly, in 36\% of countries such as Austria, Spain, Belgium (that is, countries with a high moral potential of society and trust in public administration bodies) there is a presumption of consent. At the same time, the average number of organ transplants from a corpse donor in countries with a presumption of refusal and a presumption of consent does not significantly differ (including the population) -28.9 and 32.8 transplants per million population, respectively (Gorodetska, 2012).

In addition, the presumption of refusal makes it possible to better protect the rights and freedoms of citizens, especially in countries with unstable economies, lack of trust in state institutions. The solution to the issue of increasing the number of organs taken from a corpse donor lies in the plane of the social sphere, the media, the activation of the work of public organizations and, what is important, religious communities. The most common reasons for refusal by relatives are hope for recovery when it comes to brain death while maintaining other somatic functions, unwillingness to take responsibility, aggressive or inappropriate behaviour of medical personnel in matters of potential donation. Despite this, it is widely believed among transplantologists that the introduction of the presumption of refusal stopped the development of Ukrainian transplantology (Gorodetska, 2012). 
In the world community, there are certain disagreements in the legal regulation of transplantation and donation issues, their application and control. In the practice of foreign countries, various legal models of law regulation of organs recovery from the deceased have developed - "presumption of consent" and "presumption of refusal". Each model of legal regulation of organs or tissues recovery from a deceased seeks to maximally take into account his lifetime will, but none of them, unfortunately, is not devoid of shortcomings and serious objections (Myslyva, 2005).

The "presumption of consent" is also known in the legal literature as "presumptive consent" or "denial model". According to it, the extraction and use of organs from the deceased is carried out if the deceased did not express objections to this during his lifetime, or if his relatives or legal representatives did not express objections. However, if the health care institution at the time of seizure is informed that during his lifetime the person, his relatives or legal representative expressed their disagreement with the recovery of his organs and (or) tissues after death, then the seizure is not carried out (Chebotaryova, 2003). This type of presumption is used in Belgium, Belarus, Russia, Israel, Spain, Italy, Austria and Great Britain. One of the countries where the presumption of consent to organ harvesting for transplantation in the event of a person's death is currently applied is Belarus. Belarus adopted the law seven years ago, which laid down the presumption of consent, and increased the number of transplant operations 40 times. After the amendments were made to the legislation in Belarus, the deficit of organs disappeared, they began to save thousands of people, and even make money on this. Today our patients go to Belarus to transplant hearts or other organs and pay a lot of money for this - \$100-120 thousand (Todurov Boris, 2017). In this country, half a thousand organ transplants are carried out a year. The waiting time for a donor kidney is the smallest in Europe. All operations for the citizens of the country are done free of charge. For all the time there was not a single criminal case related to the illegal removal of organs (Romanyuk, 2021). Today, this country ranks first among the post-Soviet countries in terms of the number of organ and other anatomical tissue transplants performed (Anikina, 2010).

China has become a negative example of the application of the principle of "presumption of consent", where the problem of lack of donor material is solved by removing organs from executed prisoners. This requires three conditions: first, if the body of a prisoner is not required; second, if the prisoner has given consent; third, if the prisoner's relatives also agreed. However, it is believed that China does not adhere to these conditions. The executions were planned for the day of the transplant. It has been estimated that the state receives two to three thousand organs per year from executed convicts. However, this practice cannot serve as a model for other states, because regardless of the legal status of individuals, the fundamental rights of potential donors must be respected and protected (Fabre, Murphy, Matesanz, 2010).

"Presumption of refusal" (informed consent) means that a person during his lifetime explicitly stated his consent to the recovery of an organ (s) or his family members clearly express their consent to such actions in the event that the deceased did not leave such a statement. In such cases, the lack of consent is considered a refusal to transplant. This legal model of organs and tissues recovery from a deceased donor for transplantation makes it impossible to empower doctors with the right to dispose of the body of the deceased without separate permission. According to this principle, it is believed that each person initially does not agree that his organs will be transplanted to another person (Anikina, 2010). This presumption is valid in the USA, Denmark in Ukraine. 
To date, legal science distinguishes another legal model of organ transplantation from a deceased donor - the "principle of requested consent" for posthumous donation. M. S. Bryukhovetska suggests that under this principle a person, or members of his family, give consent to organ harvesting after death based on the full, objective information they received about the possibility of organ transplantation of the deceased. "Requested consent", according to the author, differs from others in that an informed patient or his relatives are asked by medical workers about granting permission or a ban on the use of organs after death (Fabre, Murphy, Matesanz, 2010). Accordingly, in our opinion, it is inappropriate to correlate or identify the above principles, namely "presumption of refusal" and "presumption of requested consent", which some scholars equate with each other, we consider it inappropriate, since these are categories that differ in meaning and content.

As for the problems of popularizing transplantation development, it should be noted that it is at a rather low level.

Accordingly, popularization of donation and transplantation is defined as "promotion" or activity that is aimed at supporting something, or as activity aimed at drawing attention to something in order to raise awareness among the population; also as an advertising campaign organization activity (English Oxford Living Dictionary).

The transplant community is interested in promoting donation, its popularization, which is a working tool for increasing the number of organs available for transplantation. Directly popularizing transplantation is aimed to increase the number of donors with the help of informed consent for transplantation; through the introduction of mechanisms of financial and non-financial incentives (Held, McCormick, Ojo, Roberts, 2016) donation; by optimizing medical protocols that relate to the communication of medical professionals with family members of donors; by organizing and conducting educational events and other advertising campaigns to increase the donation rating (Morgan, 2011).

It should be noted that the popularization of transplantation should be carried out in all the most relevant and accessible media and on the Internet. The popularization of donation should be based on an educational mission, which essentially boils down to the most complete informing of the population about transplantation and the purpose of which should be so that every citizen can weigh the merits in the field of transplantation and can express a desire or unwillingness to become a donor.

It should be noted that the leaders in the field of popularization of transplantation are Spain (46.9 donors per 1 million of population), Portugal (34.0 donors per 1 million of population), Belgium (33, 6 donors per 1 million of population), Croatia (29.8 donors per million of population) and the United States (46.3 donors per million of population).

Spain is the direct leader in the number of donors in the world with 30 years of experience. It is in Spain that purposeful activities for the development of transplantation are taking place through educational activities, which are quite actively supported by the population. In order to popularize posthumous donation, various means of informing the population are used through round-the-clock "hot lines", relevant websites, where you can always submit questions and get a comprehensive answer. These sites are a fairly common informant about transplantation both among ordinary citizens and among medical workers, where you can get medical, legal or statistical information about donation. This is what increases and improves the informational impression about transplantation and gives people confidence in this type of activity, around which a positive atmosphere is formed based on full trust and transparency. 
In Portugal and Croatia, there are "adaptation" versions of the Spanish model for transplantation, which quite clearly reproduce the organizational and legal aspect of its components, adjusted for local characteristics. There are several methods of transplantation, namely in Croatia in 2005 the New Life as a Gift program was launched, and since 2006, National Donor Day is celebrated annually, as well as European Donor Day, that is events where participants are invoked in an unobtrusive manner to support donation and say "YES to donation!" and at the same time register at the transplant centre as a donor.

In Portugal, since 2009, there has been a public awareness program on transplantation, which was launched by the Portuguese Transplant Organization (Autoridade para os Serviços de Sangue e da Transplantação), in 2007 it was replaced by the "Portuguese Transplant Organization"), which received the blessing of the Catholic Church (Australian Government Initiative).

Regarding transplantation in Belgium, it should be noted that their transplant centres became the basis of the Eurotransplant organization, which was founded in 1967. It was in Belgium for the first time in the world in 1963 that organ explantation was carried out from a donor who was diagnosed as having brain death.

Even today, transplantation in Belgium is quite relevant, there is a progressive program for the exchange of donor organs, and an ambiguous form of organ donation after euthanasia is used (Detry, Van Deynse, Van Vlierberghe, Pirenne, 2017).

At the same time, it should be noted that the principle of "presumption of consent" is officially applied in the areas under study. In Spain, in most cases, medical professionals try to obtain from the relatives of the deceased person the consent to organs recovery (Fabre, Murphy, Matesanz, 2010).

With the so-called "nominal" presumption of consent, an important and non-obvious effect can be observed: the doctor goes to a meeting with the relatives of the deceased, neglecting the current legal norms, consoles them with a conversation and ultimately obtains consent for explantation. "Non-compliance" with the law, in this case, unites the doctor with the relatives of the deceased, makes them, in a sense, like-minded people (Reznik, Reznik, 2018)

With regard to transplantation in the United States, the use of organs for transplantation is possible only after obtaining the informed consent of the future donor or his family members. It follows from this that every American may find himself in a situation where he will need to make a decision on organ donation, which means that campaigns to promote donation should have an appropriate scope (Reznik, Reznik, 2018).

A significant contribution to the field of transplantation in the United States was the introduction of amendments and additions to the legislation on the public health service (Public Health Service Act) in terms of raising public awareness about the donation of organs and other human anatomical materials, increasing the number of donors through educational work among the population and patients resulting in increased availability of organ transplants. On a positive note in US support for transplantation, the government has approved a Funding Plan for Donation Development Initiatives in the form of educational events, presentations and various other research activities, for which, on a "guaranteed basis", costs of $\$ 5,000,000$ are provided for each financial year. (Organ Donation Awareness and Promotion Act of 2015).

Donor organizations work well in the USA. Also in America there is a principle of "presumption of refusal" on the provision of their organs for transplantation after death. However, thanks to the widespread distribution of donation as a noble cause, saving the life 
of a neighbour, people massively agree to posthumous organ harvesting. Donate Life America, for example, has over 150 million registered potential donors. These are people who voluntarily agreed to become posthumous donors. Americans are told about donation at school. Famous people, officials encourage by their own example, signing a consent. The Church also strongly supports transplantation. After all, the appropriate outdoor advertising works. Every spring, Los Angeles hosts a memorial parade with organ transplants and relatives of posthumous donors (Lysytska, 2020).

So, having carried out a deep analysis of the development of transplantation in different countries, we believe that in any activity, including the activity of transplanting organs and other human anatomical materials, it is necessary to popularize it at all levels of public administration.

It is necessary to pay attention to the fact that in Ukraine significant funds are allocated for transplantation of organs and other human anatomical materials abroad (in Belarus and India). Several hundred Ukrainians receive financial assistance, and the annual estimated need for the total number of transplants in our country is about 3.5 thousand people. According to the calculations, the cost of transplantation of various organs in Ukraine is 7-10 times less than in Europe. In accordance with this, with the introduction of an effective Transplantation system in Ukraine for the same money that is spent on the treatment of patients in need of transplantation abroad, it is possible to provide the estimated need for such operations in almost full volume directly in our country (Koval, Rudenko, 2018; Strelchenko, Bass, Gorbach-Kudrya, Myrgorod-Karpova, 2021).

In order to solve the problem of financing and material and technical support of transplantation in Ukraine, it is necessary to include in the government program "Affordable Medicines" all the costs of transplanting organs and other anatomical materials of a human being. Also, the State budget needs to provide funding for the material and technical base necessary for transplantation. At the same time, it is necessary to introduce universal compulsory health insurance, which also provides, in addition to treatment, transplantation of organs and other human anatomical materials.

In our opinion, transplantation in Ukraine should become an absolutely standard type of medical care that Ukrainians can receive in their own country without going abroad to receive it.

That is why it is necessary to introduce funding for an information system at the state level, which should maintain a register of donors and recipients, which greatly simplifies and speeds up the search for donors and recipients, the ratio and selection of a donor and recipient pair. It is the Unified Database of the Register of Donors and Recipients that will contain information about the waiting list of the donor organ and determine the order of recipients and their urgency.

In Ukraine, in 2009, the Base of the All-Ukrainian Register of Donors of Hematopoietic Bone Marrow Stem Cells was created, in which, as of May 01, 2021, there are only 53 potential donors, which explains its actual inability to provide donor material for cell transplantations. The small number of cell donors is determined by the fact that in Ukraine, cell transplants from an unrelated donor are not performed, and the number of bone marrow cell transplants from a related donor does not exceed ten per year (Komarov, Nikonenko, Salyutin, Palyanytsya, 2013).

It is such a difficult internal situation with cell transplantation that makes the citizens of Ukraine solve this issue through treatment abroad, which, first of all, imposes a burden on the state budget and causes social tension in society. Moreover, it should be noted that the 
cost of transplantation from an unrelated donor in Europe is more than 200 thousand euros, while a similar transplant in Ukraine will cost up to 500 thousand UAH. (Komarov, Nikonenko, Salyutin, Palyanytsya, 2013).

It is also advisable to provide funding for the development of a single aeromedical space throughout Ukraine, with the development of which the rapid delivery of donor organs to the recipients will be carried out, regardless of which city they are located in.

It should be noted that transplantation in Ukraine has a rather significant economic aspect. Let's take, for example, the cost of a procedure such as haemodialysis, which is quite an expensive treatment and without which the patient is doomed to die, or to a kidney transplant. So, per year the cost of haemodialysis per patient is 180-200 thousand UAH, and peritoneal one is 200-280 thousand UAH. Accordingly, the cost of a kidney transplant and drug treatment provision is 160-190 thousand UAH, and in subsequent years of the post-transplant period is approximately 20-50 thousand UAH. It follows from this that kidney transplantation is 3-4 times cheaper than annual haemodialysis.

Today in Ukraine there are more than 4 thousand patients on haemodialysis, which is 65.2 per 1 million of the population with an average need of 300 to 800 per 1 million of population (according to the European register). Due to the insufficient development of the transplant service, citizens of Ukraine are forced to receive transplant assistance abroad, which is economically unprofitable (Gorodetska, 2012).

Thus, the example of kidney transplantation testifies to the unconditional economic feasibility of organ transplants only from the standpoint of material support, which does not take into account a weighty fact - the patient's social and labour integration into society (Komarov, Nikonenko, Salyutin, Palyanytsya, 2013).

Simultaneously with the financing of transplant interventions abroad, the development of the transplant service is actually not funded by the state. The state social program "Transplantation" was funded by 55\% of the planned. Funding is mainly targeted on the procurement of immunosuppressive drugs and partly for equipment. It should be noted that the planned amount for the Program was calculated at 2019 prices, and the price growth rate for 2020-2021 was not taken into account. Provision of regional centres for transplantation is laid on local health budgets, practically reduced to financing salaries and utilities (Gorodetska, 2012).

Funding for the process of extracting anatomical material (compensation to health care institutions for consumables, depreciation of equipment, etc.) is generally not provided for by the budget, which negatively affects the number of cadaveric transplants (Komarov, Nikonenko, Salyutin, Palyanytsya, 2013).

According to analysts' estimates and medical reviews, transplantation, including the cost of therapy to restore the body after surgery, costs almost half as much as maintenance therapy such as haemodialysis. However, for some reason this progressive method of treatment is ignored in Ukraine, and the production capacities of medical institutions in this area are used by $15-25 \%$, or not used at all. Thus, at present, the situation in transplantation is very sad: with a huge demand for such operations, very few of them are carried out, and public funds are spent on the treatment of citizens abroad, although in Ukraine it would be many times cheaper (Kraynik, Sachuk, 2018). 


\section{CONCLUSIONS}

So, based on the above, we state that the field of transplantation is characterized by a number of problems that arise due to the chronic underfunding of its development, namely: 1) the lack of clear vertical subordination of public administration subjects in the field of transplantation during recovery of donor organs; 2) the lack of the principle of "presumption of consent" in the activity of transplantation and its absence at the legislative level; 3) low level of popularization of organs and other human anatomical materials transplantation; 4) insufficient procedures for diagnosing brain death as a mandatory medical procedure that must precede the recovery of a donor organ for the purpose of transplantation to a recipient; 5) insufficient funding and material and technical support for conducting research on the compliance of the donor organ with the recipient and the absence of a single register of donors and recipients; 6) lack of a unified database for registration of recipients and donors; 7) the absence of a single controlling body of public administration in the field of transplantation; 8) lack of funding for the field of transplantation at all stages of its implementation; 9) the absence of an ombudsman in the field of health care, whose powers should include the protection of the rights of donors, recipients and medical transplant specialists; 10) imperfection of legal responsibility for violation of the mechanism of transplantation of organs and other anatomical materials of a human being, result in forming negative attitude of citizens towards "black transplantation"; 11) the lack of a course of transplantation in medical institutions, resulting in medical workers ignorance in the field of transplantation.

\section{REFERENCES}

A second heart transplant was performed in Kovel. Official site of the Ministry of Health. [Access: 18.04.2021]. Access on the internet: https://moz.gov.ua/article/news/u-koveliproveli-drugu-transplantaciju-sercja-

Anikina, G. V. (2010). Features of legal regulation of organ transplantation from a deceased donor. "Legal Ukraine”, No. 10.

Bryukhovetska, M. S. (2017). Civil law regulation of posthumous donation in Ukraine. Kyiv.

Chebotaryova, G. V. (2003). Criminal law problems of transplantation of human organs or tissues and blood donation. Kyiv.

Detry, O., Van Deynse, D., Van Vlierberghe, H., Pirenne, J. (2017). Belgian Transplantation Society (BTS). Organ Procurement and Transplantation in Belgium. „Transplantation” 101(9).

English Oxford Living Dictionary [cited 2018 Sep 29]. Access on the internet: https://en.oxforddictionaries.com/definition/promotion

Fabre, J., Murphy, P., Matesanz, R. (2010). Presumed consent: a distraction in the quest for increasing rates of organ donation. „BMJ.” 18; 341.

Goncharenko, V. (2018) For the kidney transplants you should go to Belarus, for the heart - to India: why organ transplantation in Ukraine is the exception, not the rule. ZMINA: Media resource of the Center for Human Rights. [Access: 18.04.2021]. Access on the internet: https://zmina.info/articles/za_nirkojiu_v_bilorus_za_sercem_v_indijiu_chomu_ transplantacijia_organiv_v_ukrajini_vinjiatok_a_ne_pravilo/

Gorodetska, A. (2012). Transplantation in Ukraine: who stands in the way of development and success? Ukrainian medical journal: current issues of clinical practice. Access on the 
internet: https://www.umj.com.ua/article/29255/transplantaciya-v-ukraini-xto-stoit-nashlyaxu-rozvitku-ta-uspixu

Grynchak, S.V. (2017). Transplantation under criminal law. Great Ukrainian legal encyclopedia: in 20 volumes. Kharkiv: Law. Criminal law.

Held, P.J., McCormick, F., Ojo, A., Roberts, J.P. (2016). A Cost-Benefit Analysis of Government Compensation of Kidney Donors. „American Journal of Transplantation”, 16(3).

International approaches to organ donation reform. An Australian Government Initiative website [cited 2018 Sep 29]. Access on the internet: https://donatelife.gov.au/sites/ default/files/files/OTA_Fact_Sheets_-_International_approaches_to_organ_donation_ reform_November_2013.pdf.

Komarov, M. P., Nikonenko, O. S., Salyutin, R. V., Palyanytsya, S. S. (2013). Development of transplantation in Ukraine - problems and ways to overcome them. "Modern medical technologies", No 4.

Koval, D., Rudenko, K. (2018). Organ transplantation to save lives: the role of transplant coordinator: Analytical note. Access on the internet: https://www.civic-synergy.org.ua/ wp-content/uploads/2018/04/Transplantatsiya-organiv-poryatunok-lyudskyh-zhyttiv_roltransplant-koordynatora.pdf

Kraynik G. S. (2017). Regarding the need in the presumption on consent to transplantation in Ukraine as the most effective step to prevent illegal organ transplantation. Cross-border cooperation: problems and solutions: Proceedings of the II regional round table (Kyiv, September 28-29, 2017). Kyiv.

Kraynik, G. S., Sachuk, B. P. (2018). Problems of transplantation development in Ukraine. "A young scientist.", No. 4(56).

Lysytska, I. (2020). The transplant system in the USA as an example to follow in Ukraine. Access on the internet: https://www.vz.kiev.ua/systema-transplantatsiyi-v-ssha-yak-pryklad-dlyanasliduvannya-ukrayinoyu/

Morgan, S. E. (2011). Developing, implementing, and evaluating theory-based public communication campaigns to promote organ donation Public Communication Campaigns. R. Rice, C. Atkin (Eds). Thousand Oaks (CA).

Moroz, M. (2017). More than 90,000 Ukrainians need an important organ transplant operation: an interview with Kostyantyn Rudenko, chief cardiac surgeon of the Ministry of Healthcare of Ukraine. Newspaper Express. [Access: 18.04.2021]. Access on the internet: http://expres.ua/digest/2017/05/24/244126-ponad-90-tysyachukrayinciv-potrebuyutoperaciyi-transplantaciyicogo

Musiyenko, A. V. (2004). Organ and tissue transplantation. Problematic aspects of legal regulation in Ukraine. Prosecutor's office. Man. State.

Mykhaylenko, O. O., Solovey, K. O. (2006). Transplantation of human organs and anatomical materials. Zaporizhya legal readings: materials of International scientific-practical conf. (Zaporizhya, May 18-19, 2006).

Myslyva, O. O. (2005). Donation of human organs and tissues: how should it be in Ukraine? Scientific Bulletin of the Law Academy of the Ministry of Internal Affairs of Ukraine", No. 1(20).

Organ and tissue transplantation. Access on the internet: https://www.ifnmu.edu.ua/images/ biblioteka/nashi_resursi/medichni_vistavki/2018/Peresadka_organiv.pdf

Organ Donation Awareness and Promotion Act of 2015. Access on the internet: https://www.congress.gov/bill/114th-congress/senate-bill/1435/text 
Reznik, O. N., Reznik, A. O. (2018). Popularization of the idea of posthumous organ donation: practice, problems, prospects. „Bulletin of transplantation and artificial organs” V. XX. No. 4. DOI: 10.15825/1995-1191-2018-4-112-120.

Romanyuk, Y. (2021). Posthumous donation: why Ukraine needs to learn from Belarus how to save people. Politeka. Access on the internet: https://politeka.net/uk/reading/analytics/ 406066-posmertnoe-donorstvo-pochemu-ukraine-nuzhno-nauchitsya-u-belarusi-spasatlyudej.

Strelchenko, O., Lychenko, I., Shevchenko, L. (2018). Doctrinal characteristic of public of medicines as fundamental element of state financial guarantees for the pharmaceutical sphere. „Baltic Journal of Economic Studies”, Vol. 4. No. 5. December.

Strelchenko, O., Bass, V., Gorbach-Kudrya, I., Myrgorod-Karpova, V. (2021). Administrative and legal status of subjects of the state's financial system management: innovative standards and system modernization in Ukraine. „Revista Genero e Interdisciplinaridade”. February 2021, Vol. 2. No. 01.

Strelchenko, O., Okhrimenko, S., Pavlov, D. (2020). The Role of the Institute of Medical Law in the Postmodern Society. „Postmodern Openings”, Vol. 11, No. 3.

Todurov, B. (2017). Legislative consolidation of the presumption of consent will give impetus to the development of transplantation in Ukraine - Interfax Ukraine. Access on the internet: https://ua.interfax.com.ua/news/pharmacy/464302.html.

Transplantology in Ukraine: why it is so difficult to become a donor and how doomed people can save their lives. Today. August 22, 2016.

Trinyova, Ya. O. (2015). Bioethics: transplantology. Presumption of refusal VS presumption of consent. "Legal Bulletin of Ukraine".

DOI: 10.7862/rz.2021.mmr.11

The text was submitted to the editorial office: May 2021.

The text was accepted for publication: June 2021. 
